\title{
Plankton food for benthic fish: de visu evidence of trophic interaction between rainbow wrasse (Coris julis) and pelagic tunicates (Pegea confoederata)
}

\author{
Domenico D’Alelio, ${ }^{1 *}$ Gabriella Luongo, ${ }^{2}$ Iole Di Capua ${ }^{1}$ \\ ${ }^{1}$ Stazione Zoologica Anton Dohrn, Villa Comunale, 80121 Naples; ${ }^{2}$ Amici degli abyssi Diving, Via Giuseppe Bonito 198, \\ 80053 Castellammare di Stabia, Italy \\ *Corresponding author: dom.dalelio@gmail.com
}

\begin{abstract}
Salps (pelagic tunicates) are rarely observed in nature and trophic interactions involving them mainly rely on the inspection of stomach contents of their potential predators. Moreover, salps have soft bodies that are hardly identified in potential consumers. We involved recreational SCUBA-divers and photographers in collecting de visu evidence of i) massive occurrence of salps and ii) trophic interactions involving salps as preys and benthic animals as consumers. Direct evidence of trophic interactions between salps and benthic fish was documented by photographic frames. We detected a long colony of the salp Pegea confaederata being transported by currents close to the substrate on top of Banco di Santa Croce, an underwater rocky outcrop in the Gulf of Naples (Italy). An individual of the rainbow wrasse Coris julis attacked the above-mentioned salp colony by selectively detaching individuals and biting their stomach. Our report of a trophic interaction between labrids and salps is the second in fifty years and the previous one was only indirect. In this study, citizen science allowed detecting both neglected marine animals like salps and trophic interactions involving them. Visual, direct evidence of predation on salps by benthic fish adds further knowledge about patterns of living-matter fluxes between plankton and benthos, opening new questions on the potential of global change in modifying the efficient circulation of organic matter in marine systems.
\end{abstract}

Key words: Plankton; benthos; labrids; salps; marine food-webs; coastal systems; citizen science.

Received: August 2017. Accepted: October 2017.

\section{INTRODUCTION}

Plankton and benthos are traditionally considered as distinct communities: the first living suspended in the water column, the second in strict association with the sea-bottom. However, despite the formal distinction, plankton and benthos are strongly interconnected in coastal marine ecosystems (Boero et al., 1996; Griffiths et al., 2017), in virtue of: i) continuous downward fluxes of organic detritus produced by plankton and consumed at the sea bottom; ii) intermittent upward fluxes of inorganic nutrients released by benthic bacteria; and iii) periodic formation of benthic resting stages in planktonic protists and metazoans and release of planktonic larval stages by benthic animals.

A further, but less investigated route for plankton-benthos coupling is represented by trophic interactions. These are based on fluxes of living matter among organisms set at different trophic levels and can be roughly categorized as either nonselective or selective feeding. Nonselective feeding, involving plankton unicellular producers as food source and benthic organisms as consumers, is the most renowned of such interrelationships - e.g., the remarkably strong suspension-feeding carried out by benthic organisms in shallow coastal regions (Gili and Coma, 1998; Lucas et al., 2016). Yet, selective feeding (i.e., the active catching of living preys) is seldom reported among trophic interactions involving plankton and benthos (Hoeksema and Waheed, 2012).

In this paper, we report direct, de visu evidence that the benthic Mediterranean rainbow wrasse Coris julis (Linnaeus, 1758, Labridae) selectively feeds on the colonial salp Pegea confoederata (Forskål, 1775, Thaliacea). This trophic relationship was documented in the Gulf of Naples (GoN, Tyrrhenian Sea, Mediterranean Sea, Italy) in the course of a citizen science investigation employing recreational SCUBA-diving and carried out at the top side of Banco di Santa Croce, an underwater rocky outcrop whose higher pinnacles set at the boundary between the benthic and pelagic realms. We present and describe photographic frames documenting the above-mentioned trophic relation, we discuss plankton-benthos coupling in light of the existence of trophic routes connecting pelagic tunicates and benthic fish and we eventually analyse conceptually some possible perturbations to this route induced by global change.

\section{METHODS}

The Banco di Santa Croce (BSC) is a submerged rocky outcrop located $700 \mathrm{~m}$ off the coast of Vico 
Equense, on the eastern side of the GoN $\left(40^{\circ} 40.68^{\prime} \mathrm{N}\right.$, $14^{\circ} 26,00^{\prime} \mathrm{E}$, Fig. 1). BSC includes a number of pinnacles elevating towards the sea surface while its base sets at 65 $\mathrm{m}$ below the sea level. The observations herein presented have been gathered during a recreational SCUBA-diving session carried out on top of the pinnacle named Secca Principale (SP), at -12 m. During February 2017, ten of such diving sessions were carried out. This period of observation was chosen based on the fact that the yearly maximum abundance of salps in the GoN was recorded in winter and summer (Mazzocchi et al., 2011). Pictures presented herein have been taken underwater using a Nikon D7100 camera hold into a Nauticam housing with two Sea \& Sea YS-110 $\alpha$ strobes.

In addition to visual census, reference salp abundances at basin level were gathered at the Long Term Ecological Research station MareChiara (LTER-MC, $40^{\circ} 48.5^{\prime} \mathrm{N}, 14^{\circ} 15^{\prime} \mathrm{E}$, Fig. 1) (Ribera d'Alcalà et al., 2004; Mazzocchi et al., 2011). Meso-zooplakton (0.2$20 \mathrm{~mm}$ ) were collected with a WP2 net (mouth area = $0.25 \mathrm{~m}^{2}$, mesh $=200 \mu \mathrm{m}$ ) towed vertically from $-50 \mathrm{~m}$ to sea surface. Samples were fixed immediately after collection and preserved in a $4 \%$ buffered formaldehydeseawater solution. Once in the laboratory, samples were concentrated via filtering through a smaller mesh $(<200$ $\mu \mathrm{m}$ ) and concentrated zooplankton samples were diluted with filtered seawater in a graduated cup up to a volume of 100-200 ml depending on sample richness. Aliquots of $5 \mathrm{ml}$ were then sub-sampled by Stempel pipettes and analysed in a Mini-Bogorov Chamber under the stereomicroscope at different magnifications.

\section{RESULTS}

During February 2017, the SP section of BSC appeared to be colonized by different species of algae, anthozoans, crustaceans and benthic fish, among which the two labrids species Corius julis and Thalassoma pavo (Linnaeus, 1758). Colonies of salps were also regularly detected and Pegea confoederata (Fig. 2) was one of the most recorded species. All along the same period, the average salp abundance at LTER-MC, which is almost 11
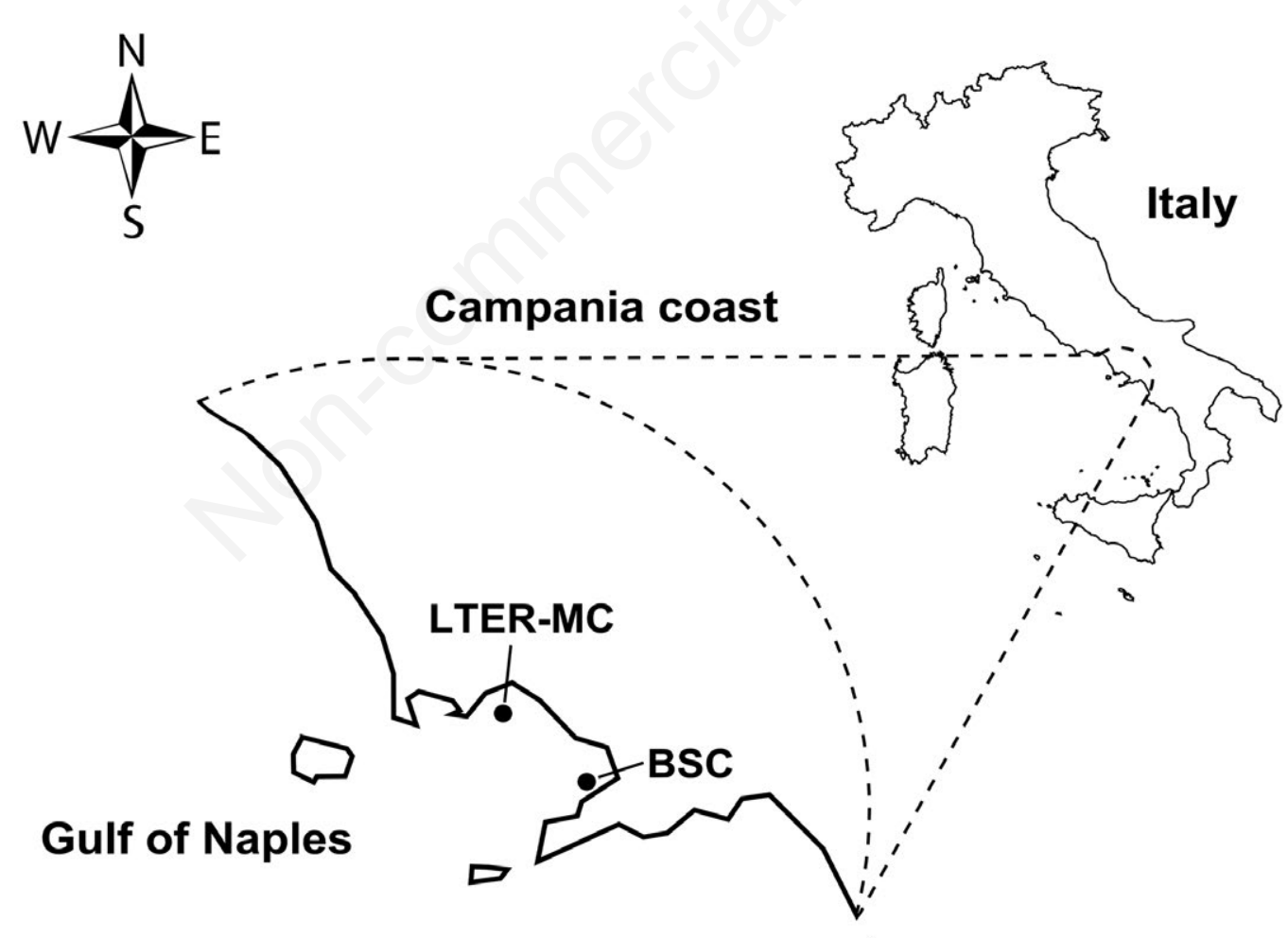

Tyrrhenian Sea

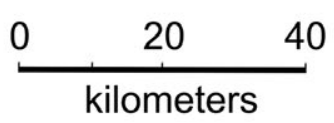

Fig. 1. The Gulf of Naples (Tyrrhenian Sea, Mediterranean Sea). Geographic localization of Banco di Santa Croce (BSC) and Long Term Ecological Research station MareChiara (LTER-MC). 
nautical miles far from BSC, accounted for 5.6 \pm 1.4 individuals per $\mathrm{m}^{-3}$. Nonetheless, $P$. confaederata was not detected in plankton samples collected at LTER-MC.

A colony of $P$. confaederata was floating in the open water in the immediacy of the BSC on 18 February 2017. This colony was transported by currents nearby the SP substrate and the following trophic interaction quickly established (Fig. 3 A-H): i) a solitary rainbow wrasse moved towards the salp colony and attacked the exterior blastozoids; ii) the fish initially bit salp's stomach, while detaching its prey from the colony; iii) in few minutes, the fish ate the interior part of the blastozoid and left the gelatinous body of the salp torn and empty; iv) the fish attacked the colony again, biting the stomach of a second blastozoid and making the latter detaching from the colony; v) the fish ate specifically the internal part of the salp at the second attack too. As soon as water-current slowly brought $P$. confoederata colony away from the proximity of the substrate and towards the open waters, the wrasse stopped eating and did not follow the chain of blastozoides. Remarkably, the wrasse did not bite pelagic crustaceans setting in the interior side of the salp body, i.e., the ovigerous females of copepod Sapphirina spp. (Thompson, 1830) (Fig. 2 B-C) and some specimens of amphipod Hyperiidea (Milne-Edwards, 1830) (Fig. 2 A-B).

\section{DISCUSSION}

Coris julis is an omnivore fish with a preference for animal material (Karachle and Stergiou, 2017), it predates mainly benthic gastropods and crustaceans but even ectoparasites borne by fishes of same size (e.g., Boobs boops) or even larger (e.g., Mola mola) than labrids (Bertoncini et al., 2009; Moosleitner, 1980; Narvaez et al., 2015; Vasco-Rodrigues and Cabrera, 2015). When
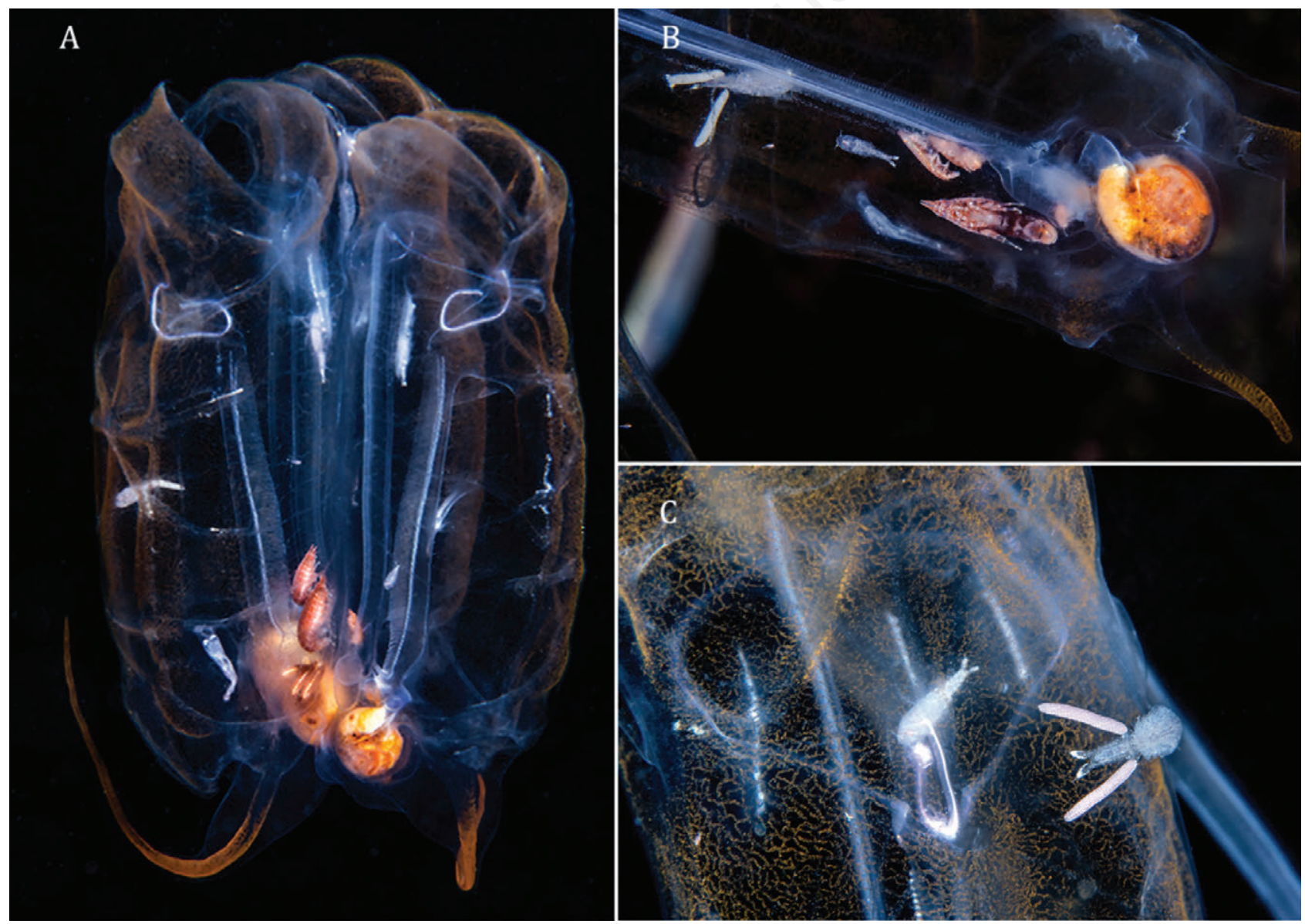

Fig. 2. The salp Pegea Confaederata at Banco di Santa Croce. A) Closer view of a colony of blastozoids, the sexual life-cycle stages. B) Closer view of salp's stomach (i.e., the orange circular organ at the right side of the picture) and of female copepods of genus Sapphirina (whitish animals) and amphipods (brownish animals) adhering to salp's body. C) Closer view of salp's 'tunic' (i.e., the gelatinous and cellulose-based body envelop) and of parasitic Sapphirina spp. 


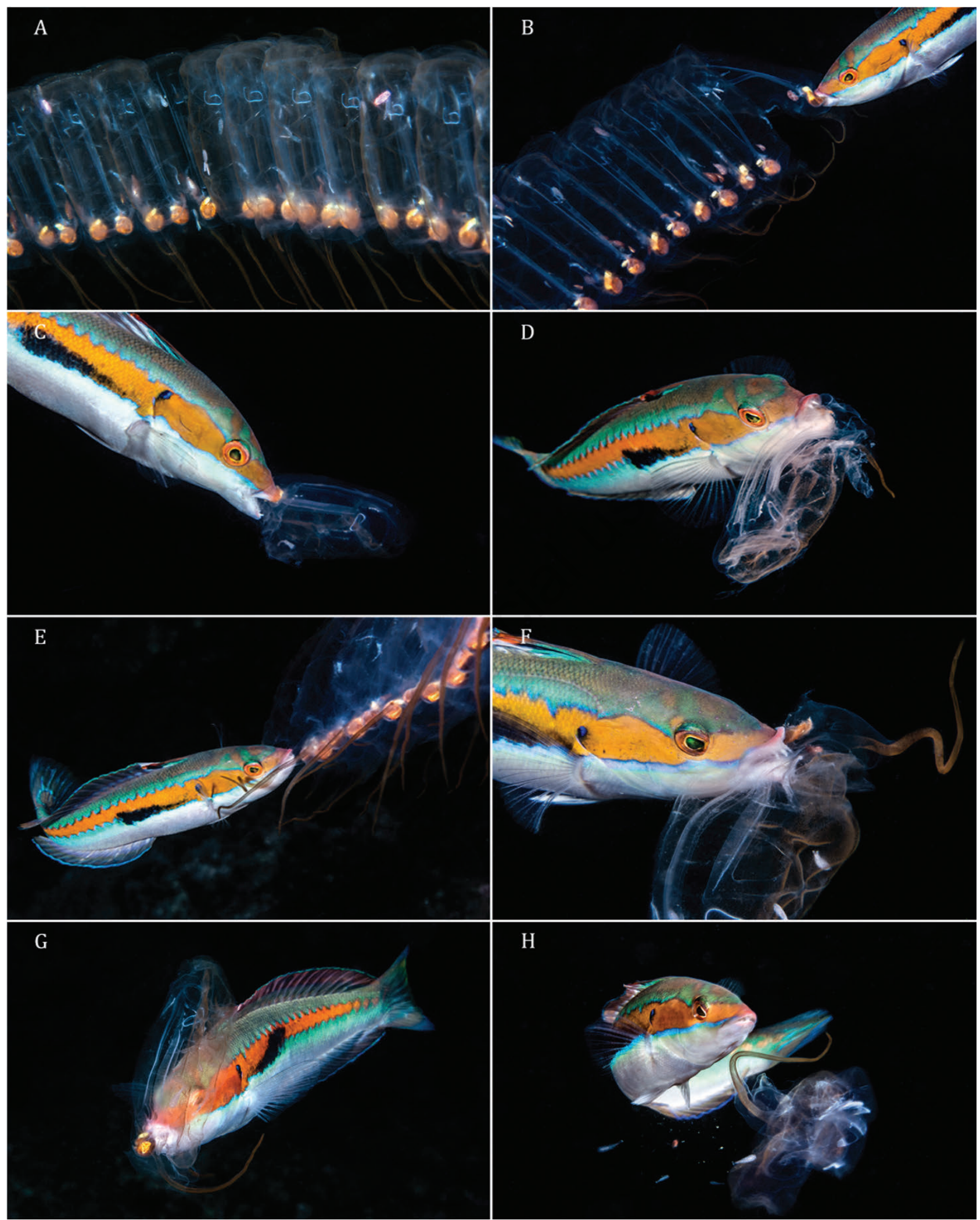

Fig. 3. Labrid predation on salps at Banco di Santa Croce. A) Long colony of Pegea confaederata blastozooids. B-H) Different phases of the predatory attack made by an individual of Coris julis on a colony of the salp; B) the fish removes a single blastozoid from the salp colony; C-D) the fish eats selectively the stomach of the salp individual; E-F) the fish attacks the prey following the same modality as above; H) the fish does not eat the gelatinous envelop of the salp. 
behaving as a cleaner, $C$. julis is an opportunist feeder searching for preys attached to swimming hosts, which are inspected by means of high frequency bites (Narvaez et al., 2015). This consideration let us hypothesize that the trophic interaction reported herein arose from the visual attraction exerted by the slow moving and macroscopic salp-colony on the wrasse. This latter was plausibly attracted by the coloured (and nutritive) stomach placed at the lowest portion of the salp body. We cannot exclude that $C$. julis confused the salp stomach with an ectoparasite.

Salps are important components of the diet of 149 species of fishes (a review is presented in Henschke et al., 2016). Nonetheless, only one labrid species was reported to predate salps to date, i.e., the tropical wrasse Clepticus parrae, whose stomach included mainly plankton, and salps accounted for $4.7 \%$ of total ingested food (Randall, 1967). There is no report of predation on salps by Mediterranean-wrasses to date, but salps are soft-bodied animals, they are digested rapidly and their identification by means of interior inspection of potential predators is weakly effective. Salps represent good targets to intermediate predators, including small fish, for a number of reasons: i) salps are macroscopic and easily detectable; ii) while feeding, they slowly move thanks to pulse movements of their gelatinous body and this may favour encounter with predators (Bone, 1998); iii) salps' energetic value is relatively high (Henschke et al., 2013), since they concentrate a big amount of organic material via filter feeding, with preference on smaller and more nutritive plankton particles (Sutherland et al., 2010).

Salps are an apparently infrequent food for fish, probably because they have patchy geographic distributions and aperiodic population growths. The major demographic increases of these gelatinous organisms usually coincide with sudden and short-lived swarms of long colonies (up to $20 \mathrm{~m}$ in length) formed by specific life-cycle stages called blastozoides (Boero et al., 2013). The latter reproduce sexually and alternate with the solitary form called oozoid, which reproduces asexually via the release of colonial aggregates of blastozoids. Classical mesozooplankton sampling activity (e.g., WP2 net with vertical haul operated from research vessels) are not suitable for detecting salp outbreaks since in many cases samplers destroy colonies. Lack of systematic observations of salp populations is probably at the base of the dispute about the actual increase of these organisms in the present warming oceans (see Condon et al., 2012). Nonetheless, salps may be favoured in the future oceans by: i) the positive effect of temperature on their feeding and reproductive performances (Bone, 1998); ii) their potentially high physiological adaptation to lower phytoplankton concentrations (Deibel and Paffenhofer,
2009), and the latter are significantly regressing in the global ocean since the beginning of last century (Boyce et al., 2010); iii) their higher affinity to pico- and femtoplankton particles (Sutherland et al., 2010), whose relative dominance is thought to be expanding in warmer oceans (Peter and Sommer, 2013), in consequence of reduced nutrient availability in the photic zone (Chust et al., 2014).

In consequence of global warming, Mediterranean wrasses are experimenting changes in latitudinal and bathymetric distributions of their populations (Milazzo et al. 2011, 2016), and such changes can synergistically interact with salps' increase and affect marine food-web structure and dynamics. Coris julis is a cold-adapted species and water-temperature rising will induce in this fish both weaker physiological performances and shifting of feeding activity towards epibenthic organisms (Milazzo et al., 2013); indeed, these latter lay on a still substrate (contrarily to ectoparasites, most of them laying on moving animals) and can be more easily caught. The possible demographic regression of $C$. julis populations may be flanked by increasing relative dominance of the sympatric T. pavo (Milazzo et al., 2013), which is reported to feed on a less diverse array of preys (Narvaez et al., 2015) and it is apparently less attracted by salps (according with the present study). In a context of water-temperature rising, the present winner (the warm-adapted T. pavo) is not necessarily a 'fitter' winner, because it is apparently less prone to adapt its trophic behaviour to relatively more available resources, such as salps.

Benthic ecosystems sustain coastal fisheries (Kritzer et al., 2016) and are also severely impacted by global change (Harley et al., 2006), with temperature rising inducing major ecological detriments (e.g., Rivetti et al., 2014). Even if plankton differ in many aspects from benthos, the interaction between these dominions can impact coastal food webs (Boero et al., 1996; Griffiths et al., 2017); to this respect, interaction with benthos should be integrated within conceptual and computational models of plankton food-webs, which are still at their infancy (e.g., D'Alelio et al., 2016a, 2016b).

\section{CONCLUSIONS}

In conclusion, underwater rocky crops are promising study-sites for plankton-benthos coupling: they are highly productive sites (Pitcher et al., 2008), represent ideal points of junction between planktonic and benthic communities, provide suitable conditions for the establishment of trophic interactions among organisms that are mainly associated to one of these sub-systems and, ultimately, they are relatively easily accessible to SCUBA-divers. To the latter respect, observational studies supported by citizen scientists are particularly promising. 


\section{ACKNOWLEDGEMENTS}

DDA and IDC thank the Flagship Project RITMARE - The Italian Research for the Sea - coordinated by the Italian National Research Council and funded by the Italian Ministry of Education, University and Research within the National Research Program 2011-2013 for providing funds.

This work is dedicated to the memory of Ugo Di Capua, a pioneering scuba diver at Banco di Santa Croce.

\section{Conflict of interest}

The authors declare no competing interests.

\section{Ethical statement}

This article does not contain any studies with human participants or animals performed by any of the authors. Data included herein have been collected in nature as photographic material of living animals in their specific environment.

\section{REFERENCES}

Bertoncini ÁA, Machado LF, Barreiros JP, Hostim-Silva M, Verani JR, 2009. Cleaning activity among Labridae in the Azores: the rainbow wrasse Coris julis and the Azorean blue wrasse Centrolabrus caeruleus. J. Mar. Biol. Assoc. UK 89:859-861.

Boero F, Belmonte G, Bracale R, Fraschetti S, Piraino S, Zampardi S, 2013. A salp bloom (Tunicata, Thaliacea) along the Apulian coast and in the Otranto Channel between MarchMay 2013. F1000Research 2:181.

Boero F, Belmonte G, Fanelli G, Piraino S, Rubino F, 1996. The continuity of living matter and the discontinuities of its constituents: Do plankton and benthos really exist? Trends Ecol. Evol. 11:177-180.

Bone Q, 1998. The biology of pelagic tunicates. Oxford University Press, Oxford: 362 pp.

Boyce DG, Lewis MR, Worm B, 2010. Global phytoplankton decline over the past century. Nature 466:591-596.

Chust G, Allen JI, Bopp L, Schrum C, Holt J, Tsiaras K, Zavatarelli M, Chifflet M, Cannaby H, Dadou I, Daewel U, Wakelin SL, Machu E, Pushpadas D, Butenschon M, Artioli Y, Petihakis G, Smith C, Garçon V, Goubanova K, Le Vu B, Fach BA, Salihoglu B, Clementi E, Irigoien X, 2014. Biomass changes and trophic amplification of plankton in a warmer ocean. Glob. Chang. Biol. 20:2124-2139.

Condon RH, Graham WM, Duarte CM, Pitt KA, Lucas CH, Haddock SHD, Sutherland KR, Robinson KL, Dawson MN, Beth M, Mills CE, Purcell JE, Malej A, Mianzan H, Uye S, 2012. Questioning the rise of gelatinous zooplankton in the world's oceans. Bioscience 62:160-169.

D'Alelio D, Libralato S, Wyatt T, Ribera d'Alcalà M, 2016a. Ecological-network models link diversity, structure and function in the plankton food-web. Sci. Rep. 6:21806.

D'Alelio D, Montresor M, Mazzocchi MG, Margiotta F, Sarno D,
Ribera d'Alcalà M, 2016b. Plankton food-webs: to what extent can they be simplified? Adv. Oceanogr. Limnol. 7:5646.

Deibel D, Paffenhofer G-A, 2009. Predictability of patches of neritic salps and doliolids (Tunicata, Thaliacea). J. Plankton Res. 31:1571-1579.

Gili JM, Coma R, 1998. Benthic suspension feeders: their paramount role in littoral marine food webs. Trends Ecol. Evol. 13:316-321.

Griffiths JR, Kadin M, Nascimento FJA, Tamelander T, Törnroos A, Bonaglia S, Bonsdorff E, Brüchert V, Gårdmark A, Järnström M, Kotta J, Lindegren M, Nordström MC, Norkko A, Olsson J, Weigel B, Žydelis R, Blenckner T, Niiranen S, Winder M, 2017. The importance of benthicpelagic coupling for marine ecosystem functioning in a changing world. Glob. Chang. Biol. 23:2179-2196.

Harley CDG, Hughes AR, Hultgren KM, Miner BG, Sorte CJB, Thornber CS, Rodriguez LF, Tomanek L, Williams SL, 2006. The impacts of climate change in coastal marine systems. Ecol. Lett. 9:228-241.

Henschke N, Bowden DA, Everett JD, Holmes SP, Kloser RJ, Lee RW, Suthers IM, 2013. Salp-falls in the Tasman Sea: a major food input to deep-sea benthos. Mar. Ecol. Prog. Ser. 491:165-175.

Henschke N, Everett JD, Richardson AJ, Suthers IM, 2016. Rethinking the role of salps in the ocean. Trends Ecol. Evol. 31:720-733.

Hoeksema BW, Waheed Z, 2012. It pays to have a big mouth: mushroom corals ingesting salps at northwest Borneo. Mar. Biodivers. 42:297-302.

Karachle PK, Stergiou KI, 2017. An update on the feeding habits of fish in the Mediterranean Sea (2002-2015). Mediterr. Mar. Sci. 18:43-52.

Kritzer JP, DeLucia MB, Greene E, Shumway C, Topolski MF, Thomas-Blate J, Chiarella LA, Davy KB, Smith K, 2016. The importance of benthic habitats for coastal fisheries. Bioscience 66:274-284.

Lucas LV, Cloern JE, Thompson JK, Stacey MT, Koseff JR, 2016. Bivalve grazing can shape phytoplankton communities. Front. Mar. Sci. 3:1-17.

Mazzocchi MG, Licandro P, Dubroca L, Di Capua I, Saggiomo $\mathrm{V}, 2011$. Zooplankton associations in a Mediterranean longterm time-series. J. Plankton Res. 33:1163-1181.

Milazzo M, Mirto S, Domenici P, Gristina M, 2013. Climate change exacerbates interspecific interactions in sympatric coastal fishes. J. Anim. Ecol. 82:468-477.

Milazzo M, Palmeri A, Falcón JM, Badalamenti F, GarcìaCharton JA, Sinopoli M, Chemello R, Brito A, 2011. Vertical distribution of two sympatric labrid fishes in the Western Mediterranean and Eastern Atlantic rocky subtidal: Local shore topography does matter. Mar. Ecol. 32: 521-531.

Milazzo M, Quattrocchi F, Azzurro E, Palmeri A, Chemello R, Di Franco A, Guidetti P, Sala E, Sciandra M, Badalamenti F, García-Charton, JA, 2016. Warming-related shifts in the distribution of two competing coastal wrasses. Mar. Environ. Res. 120:55-67.

Moosleitner H, 1980. Cleanerfish and cleanershrimps in the Mediterranean. Zool. Anz. 205:219-240.

Narvaez P, Furtado M, Neto AI, Moniz I, Azevedo JMN, Soares MC, 2015. Temperate facultative cleaner wrasses selectively 
remove ectoparasites from their client-fish in the Azores. Mar. Ecol. Prog. Ser. 540:217-226.

Peter KH, Sommer U, 2013. Phytoplankton cell size reduction in response to warming mediated by nutrient limitation. PLoS One 8:1-6.

Pitcher TJ, Morato T, Hart PJB, Clark MR, Haggan N, Santos RS, 2008. Seamounts: ecology, fisheries and conservation. Wiley-Blackwell, Hoboken: 552 pp.

Randall JE, 1967. Food habits of reef fishes of the West Indies. Institute of Marine Sciences, University of Miami Coral Gables: 94 pp.

Ribera d'Alcalà M, Conversano F, Corato F, Licandro $\mathrm{P}$, Mangoni O, Marino D, Mazzocchi MG, Modigh M, Montresor M,
Nardella M, Saggiomo V, Sarno D, Zingone A, 2004. Seasonal patterns in plankton communities in a pluriannual time series at a coastal Mediterranean site (Gulf of Naples): an attempt to discern recurrences and trends. Sci. Mar. 68:65-83.

Rivetti I, Fraschetti S, Lionello P, Zambianchi E, Boero F, 2014. Global warming and mass mortalities of benthic invertebrates in the Mediterranean Sea. PLoS One 9:1-22.

Sutherland KR, Madin LP, Stocker R, 2010. Filtration of submicrometer particles by pelagic tunicates. P. Natl. Acad. Sci. USA 107:15129-15134.

Vasco-Rodrigues N, Cabrera PM, 2015. Coris julis cleaning a Mola mola, a previously unreported association. Cybium 39:315-316. 